\title{
Akunah Puleh - Awaken, You Spirits
}

Ritual and Gender in Maritime Southern Thailand

Akunah Puleh - Awaken, You Spirits. Ritual and Gender in Maritime Southern Thailand

Akunah Puleh - Despertad, espíritus. Ritual y género sexual en la Tailandia maritima del Sur

\section{Olli Ruohomäki}

\section{OpenEdition}

\section{Journals}

\section{Electronic version}

URL: https://journals.openedition.org/tc/308

DOI: $10.4000 /$ tc.308

ISSN: 1952-420X

\section{Publisher}

Éditions de l'EHESS

\section{Printed version}

Date of publication: 1 January 2001

Number of pages: 479-497

ISSN: 0248-6016

\section{Electronic reference}

Olli Ruohomäki, "Akunah Puleh - Awaken, You Spirits", Techniques \& Culture [Online], 35-36 | 2001, Online since 11 September 2012, connection on 29 September 2022. URL: http://journals.openedition.org/tc/ 308 ; DOI: https://doi.org/10.4000/tc.308

This text was automatically generated on 29 September 2022.

All rights reserved 


\title{
Akunah Puleh - Awaken, You Spirits
}

\author{
Ritual and Gender in Maritime Southern Thailand
}

Akunah Puleh - Awaken, You Spirits. Ritual and Gender in Maritime Southern

Thailand

Akunah Puleh - Despertad, espíritus. Ritual y género sexual en la Tailandia

maritima del Sur

Olli Ruohomäki

1 This article explores the annual boat-blessing ceremony -Puleh - as practised by smallscale fishermen in the Thai Muslim maritime communities of Phangnga Bay, Southern Thailand ${ }^{2}$. The main thrust of the article is that the Puleh serves to renew and strengthen the social relationships between the genders and between the living and the dead. Despite social and economic transformations in local livelihoods the Puleh retains its significance in local social practises as attested by the fact that a Puleh is also performed on fishing boats that have been turned into sightseeing boats for tourists. Instead of a good fishing season, a good tourist season is asked.

Before exploring the Puleh ceremony in detail I situate the maritime communities under scrutiny in the ecological context and provide a view on the local fishing practices and other sources of livelihood. After unravelling the Puleh ceremony, I explore its sociological significance in the life worlds of the local villagers and provide an argument why the Puleh continues being practised despite social and economic transformations in Phangnga Bay.

\section{Ecological Context}

3 The Andaman Sea coast, in which Phangnga Bay is found, differs greatly from the rest of Thailand. The coastline is rugged, remarkably spectacular, sometimes even surrealistic. Small fishing villages hidden away in emerald blue-green bays alternate with soaring limestone cliffs covered with lush tropical vegetation. Mountain streams join and form short rivers. These flow to the sea, forming narrow alluvial flood plains at the river mouths. Most of the coastline inside the outer islands consists of dense 
mangrove swamps thick with mudskippers. Here the monotony of the mangrove swamps is broken by long white beaches of quartz and coral fragments. Near the coastline there are a lot of little islands and islets with stunning coral reefs.

Most of the human settlement is concentrated at the river mouths and the occasional sand beach. A few fishing villages can be found on the islands, but most of them are on the mainland coast.

The mangroves that are found along the Phangnga Bay coast are crucial links in the local marine ecosystem. Local fishing communities depend heavily upon the mangroves. Besides supplying the population with animal protein from fish, molluscs and crustaceans that can be found in the swamps, the plants themselves have many uses : the Nipa palm provides fruits and thatching material and mangrove bark provides tannin for tanning leather. In addition, the upper leaves of the Rhizophora apiculata (kongkang bailek) are eaten as a vegetable, while the pods of the Avicennia alba (samae khao) are boiled for the edible seeds ${ }^{3}$. Furthermore, the mangroves are sources of strong and durable wood that is useful in making fishing equipment like poles for fixing nets and fish traps.

6 It is important to note that in recent years, due to its natural beauty, Phangnga Bay has become a major destination for both domestic and international tourists and consequently fishing communities have faced new challenges and opportunities in terms of sources of livelihood.

\section{Fishing Practices and Land-Based Productive Activities}

7 There are currently seven major types of fishing practised in Phangnga Bay. The most important, in terms of the number of independent operators, is fishing with line-hooks (bet) from a boat. The second, and an increasingly important type of fishing is making squid traps (sai myk). The third is using a portable fish trap (loom). The fourth, and the most important in terms of potential yield, is the nylon gill-net (uan loi), which is spread out in the sea and pulled on board the boat. A fifth type of fishing, which requires considerable investment, is building large weirs (po) on the shore and relying on the tides to catch fish. A sixth type of fishing is using a net-like device (uan run) in the front of the boat and scooping out whatever enters the device while the boat is at sea. Finally, a variety of subsistence fishing techniques are used in shallow water off the beach.

8 No individual fisherman uses all these types of fishing gear. Rather, a combination of techniques is used depending on the capital available, ecological factors, market conditions, skill and the choice of the individual.

While everyone is able to afford hooks and line and almost everyone makes squid traps or portable fish traps, only households with the necessary capital can fish with gill-nets of construct a large weir. Ecological factors govern which method can be used where and when. Changes in the wind, the weather and the migration patterns of fish affect the choice of technique. Market conditions also affect which fishing method is utilised. Matters of skill are also a factor. Constructing traps is a relatively easy task compared with constructing a sedentary weir. Some individuals prefer one technique to another 
even though they would be able to use another technique. The basis for preference is usually dictated by experience.

The boats used in Phangnga Bay region are relatively small long-tail boats (rya haang yau) with an old engine attached. The boats are narrow canoe-like craft with outboard motors. The boats are classified according to how many kong (a fore-and-aft structural member lying above the keel in the bottom of the hull) they have (photo 1). The kong is a piece of the frame to which wooden planks are attached. The kong are always in odd numbers, because even numbers would bring bad luck. Eleven kong is considered to be the smallest boat, and usually the bigger fishing boats have either 19 or 21 kong. The kong are around $50 \mathrm{~cm}$ apart. Therefore, a boat with 19 kong is around $9.5 \mathrm{~m}$ in length. The average boat with 19 kong costs around 20,000 baht. The 10 h.p. - 15 h.p. Yamaha or Yanmar motors cost around 25,000 baht. They are strong and simple to use. The engine has a long 4-5 $\mathrm{m}$ steel rod attached to it with a propeller at the end.

11 [Image non convertie]

PHOTO 1. FISHERMAN REPAIRINg A LONg-TAIL BOAT

12 This steel rod can be easily lifted and hence the boat can be driven in shallow water if need be. Besides these, a pair of chew (oars) at 200 baht a pair and a steel anchor at 250 baht are needed.

13 Retired fishermen recall that before the mechanisation of fishing boats in the late 1960s in Krabi, most fishing boats used sails and paddles to move around. The boats were about $10 \mathrm{~m}$ long with a mast in the middle of the keel and a boom with a cotton sail. Such a vessel was called a rya bai. The retired fishermen also recall that in their youth the wood that was used to construct fishing boats was a type of hard wood (mai yaang) which is difficult to find these days.

14 Most of the fishing operations done by small-scale fishermen in Phangnga Bay require only a small crew. In fact, many fishermen, especially those using simple technology such as lines and hooks, go out to sea alone. Nonetheless, the usual crew size for a longtail boat is two or three people. In most cases the crew is composed of kin. The number of sons a fisherman has is an important determinant of crew recruitment. For example, the typical crew may consist of father and an adult son, father-in-law and son-in-law, brothers-in-law.

15 Seasonal rhythms, spawning times, migration patterns of fish, phases of the moon, tidal rhythms, all these have a direct relationship with the daily life of the fisherman. When to fish, where to fish, how to fish, all these are questions that the fisherman faces every day. The answer depends to a very large extent on his knowledge of the cycles and rhythms of the environment in which he operates (see table 1 for details of seasonal fishing patterns).

16 [Image non convertie]

TABLE 1. SEASONAL FISHINg PATTERNS

17 There is a great variety in the fish species, molluscs and crustaceans that the fishermen catch in Phangnga Bay. The catch differs according to season, place and method of catching. There are over 110 fish species that the fishermen regard as having food value. This category excludes many fish species that dwell in coral reefs because they are either too small to be worth catching or poisonous. 
18 After the boat lands on the beach and the catch has been carried ashore in baskets, the distribution of the catch begins. The wives and children of the crew take fish aside for their families' own consumption. This include fish that have little market value and also some choced pieces. After this, the rest of the catch is separated into piles according to species and weighed with a scale provided by the fish dealer. The dealer, who is most often a woman, will determine the daily market value of the catch and pay accordingly. She does not necessarily pay in cash there and then, but keeps a re-cord of the catch and pays a lump sum at the end of the month.

It would be insufficient to note that contemporary Thai Muslim maritime communities in Phangnga Bay obtain their livelihood only from fishing. Fishing is by far the most important income-generating activity, but non-fishing activities such as trading, agriculture and wage labour is increasingly important. The Phangnga Bay region has been caught up in the developments that are taking place throughout Southeast Asia and consequently rural society is changing rapidly. Much of the changes in the environment and livelihood structure took place within a couple of decades and the process is still going on putting the local villagers in a somewhat uneasy position of embracing both the lifestyle characterised by a fishing way of life, and the changes modernity has brought. Nonetheless, the Puleh continues to play a significant role in villager's lives.

\section{The Ritual}

Each year after the monsoon season and a new fishing season starts in OctobetNovember, Thai Muslim fishermen perform a boat-blessing ceremony known locally as $\mathrm{Puleh}^{4}$. The history of the ceremony is somewhat unclear, but most probably it has preIslamic roots. From oral history it appears that the Phangnga Bay coast was populated by people from somewhere near Satun in the south. The word Puleh is derived from a local Malay dialect and denotes to the awakening of the guardian spirits believed to reside in the boat. The present inhabitants of Phangnga Bay coast have professed Islam as long as they recall. However, typical to this region of Sourheast Asia, folk religion plays a very important part of the people's worldview. Some of the older fishermen who are versed in elements of folk religion refer to it as sayasaat (occult). The Puleh is very much a manifestation of folk religion mixed with marine lore, which places an importance in the spirit world ${ }^{5}$. In the context of fishing communities the awakening of the spirits refers explicitly to the guardian spirits of the boats that are believed to reside in every fishing boat. These guardian spirits are called collectively as mae yaa nang rya. Mae means mother, but is also used to denote elder females, yaa nang denotes to a maiden and rya means a boat. Hence, mae yaa nang rya can be glossed as «female beings residing in the boat ». Mae yaa nang rya are female guardian spirits that look after the well-being of the boat and its crew. According to local fishermen the purpose of the boat-blessing ceremony is to ensure a success for the new fishing season by asking guidance and blessings from the guardian spirits.

The timing of the boat-blessing ceremony is important and it is performed on a date considered to be auspicious. Villagers gather on the beach early before dawn to wait for the ceremony to begin. The boats have been cleaned and prepared for the ceremony the previous evening. Local practise dictates that the ceremony is usually done at dawn and always with flood tide, never during ebb ride. The bow of the boat is always facing 
shore. This small detail has symbolic significance because as the ceremony is performed on the boat, the flood tide will carry the boat towards the shore -the shore being the destination of all fishermen after the fishing trips are completed. A boat being stuck on a sand bar during ebb tide would symbolise disaster and a bad fishing season. Mobility and movement are important for the local fisherman and being stuck on a sand bar at the beginning of the new fishing season resembles hitting an under water rock or reef during fishing operations with potentially fatal consequences.

The boat-blessing ceremony is performed by a senior man of the village, who is often a specialist in esoteric knowledge of the world beyond. He is referred to with the respectful title to mo. To is local Malay and is a title given usually to elderly men and signifies status and $m o$ is Thai and signifies a person with learning ${ }^{6}$. When the time for the ceremony comes the to mo and the owner of the boat together with his crew and family assemble on the beach. The women prepare special food for the occasion including fragrant cooked rice, chicken curry, and sweet sticky rice with coconut milk (photo 2) ${ }^{7}$. The food is first offered to the guardian spirits and when the ceremony is over, the food is shared among the to mo, owner of the boat, crew, family and friends share the food (photo 3). In addition, the offering for the spirits includes betel, turmeric, candles, incense sticks, fragrant lustral water and new strips of coloured cloth which are tied on the bow of the boat (photo 4). The food and the offerings are set on the middle plank of the boat and the to mo commences to pray. The boat is usually anchored in shallow water and only the to mo will sit inside the boat while the other individuals observe the ceremony from the shore.

I recorded the following prayer, which the to mo refers to as katha, from Lung Man who was one of the most senior to mo around Ao Phra Nang, Krabi and who was called upon to perform the boat-blessing ceremony in a number of Ao Phra Nang communities.

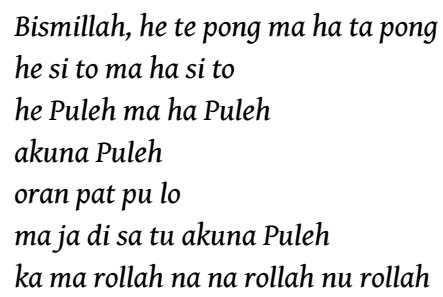

The prayer translates approximately as :

In the name of Allah

root powder

come to powder

wake up, come to wake up

I will wake you up

44 veins come to become one

I will wake up the oldest one, the middle one and the youngest one

[Image non convertie]

PHOTO 2. VILLAgERS gATHERING ON THE BEACH IN ANTICIPATION OF THE BOAT-BLESSINg CEREMONY

[Image non convertie]

PHOTO 3. THE FAMILY OF A fISHERMAN SHARINg FOOD AFTER THE BOAT-BLESSING CEREMONY

[Image non convertie]

PHOTO 4. MR HEM SPRINKLINg THE BOW OF HIS BOAT WITH LUSTRAL WATER 
first word, bismillah, is an opening statement used in all prayers asking for the blessing of Allah, a reference to Islam ${ }^{8}$. Sito refers to a kind of powder mixture made from mangrove tree bark and ground white rice. Mangrove forests are an integral part of the local marine ecosystem and the birthplace of a variety of marine animals. The powder of the mangrove bark and ground white rice symbolises food and abundance. Puleh refers to the act of waking up of the guardian spirits of the boat, known locally as mae yaa nang rya. It is worth noting that the belief in female guardian spirits is not restricted to Thai Muslims alone. I have encountered the belief among Thai Buddhist fishermen in Chumphon province in the Gulf of Thailand ${ }^{9}$. Local fishermen believe that in each fishing boat there are three female spirits which act as guardian spirits. It is believed that the spirits can help foretell storms, protect the boat from evil and help to ensure good catches. Colourful strips of cloth are tied on the bow of the boat to pay respect to the spirits. The mae yaa nang rya sometimes appears in dreams to the owner to tell that she is sick. In the morning the owner must take little pieces of wood from the boat and strings from a fishing net, mix them with betel, then he will chew and spit it throughout the boat three times. Sometimes in the dreams the mae yaa nang rya come to sleep with the boat owner signifying a good fishing expedition the next day. These female spirits have special significance in the local social world where women play a special role in the village economy and local kinship structures. Akuna is related to the Thai word $k u$ (I). $K u$ is a rather crude form of I used by fishermen when referring to themselves. In this case akuna refers to the person who is performing the rites. Only senior males of the community with specialist knowledge who acts as an intermediary between the community of the living and the dead are able to perform the ceremony. While most fishermen have a rudimentary understanding of the world of spirits (lok winyaan), it is the to mo, who knows how to handle the occult. The sentence on 44 veins becoming one is a reference to the 44 demons which inhabit the underworld in local cosmology. By calling them to become one, the to mo exhorts the powers that govern the sea to be favourable to the fishing expeditions that will be undertaken by the boat and its crew. The words used in the spell are a curious mix of local Malay and local Southern Thai. The Phangnga Bay region is very much a transition zone between Islamic Malayan world and Buddhist Thailand, hence both Malay and Thai are used in ritual language. the sea. According to the local belief there are both malevolent and benevolent spirits in the sea. The benevolent must be sought after to gain blessings and security and the malevolent must be propitiated not to harm the fishermen on their fishing expeditions. Many fishermen wear coral charms around their waists to protect themselves from evil spirits while fishing (Anderson $1988: 120$ ).

Each cape (laem), bay (ao), channel (huay), big and unusually shaped underwater rocks (hin tai nam), coral reefs (pakarang) have their respective guardian spirits or chao thi as they are locally known. Most of the guardian spirits are also known as phi jin which are said to appear as light or as fire balls. The phi jin can be either good or evil. In order to avoid troubles a fisherman must not offend the guardian spirit by asking its permission to pass the area or fish in it.

31 Lung Lat, a senior fisherman from the village of Ban Laem Pho, Krabi province, recollected to me an encounter with a phi jin during one of his fishing expeditions. One evening Lat and two others were fishing for Silver Pomfret off Lanta Island in Phangnga 
Bay. Suddenly he saw a large shoal of fish appearing. According to local custom, not a word must be uttered when such a large shoal appears. However, one of the crew members got excited and shouted something aloud and the shoal vanished. Soon a violent storm broke out and began to rain heavily. The boat rocked heavily in the waves and Lat lost consciousness. While in the state of unconsciousness Lat saw a large fireball approaching him. A human like figure in the fireball motioned Lat to come forward. Lat followed and was about to step out of the boat when he regained consciousness. One of the crew had sprinkled rice and khamin (turmeric powder) over Lat's body while calling for the mae yaa nang rya to come to the rescue and as a consequence Lat had regained consciousness ${ }^{10}$. According to Lat, a phi jin had attacked him, because as captain of the boat he had forgotten to ask permission to fish to the local guardian spirit residing in the area.

The last sentence of the prayer refers to the names of the three female guardian spirits of the boat. The spirits are said to reside in the bow, in the beam and in the stern of the boat. Some fishermen worship only one, others two and orhers three mae yaa nang rya. It is said that if the boat is about to be unleashed from its moorings the spirit in the bow will make a noise. The spirit in the middle beam of the boat will make noise if a bountiful catch is to be expected and if there is a risk that the boat will hit a reef, the spirit in the stern will make a noise.

The above prayer is said three times while the food and offerings are pulled towards each other without letting them touch one another. Then the offerings are placed first in the bow, then on the stern and lastly on the beam. The work of the to mo done, the boat owner proceeds to sprinkle the entire boat with nam mon (lustral water), which is mixed with ground white glutinous rice and mangrove bark powder, with the aid of mangrove branch. After this the old pieces of cloth hanging at the bow of the boat are replaced with new ones and the ceremony is over.

\section{Gender and Social Relations}

There are a number of ways to interpret the Puleh; explorations in the sociology of religion and the study of ritual being the most apparent. However, what is interesting in terms of local livelihood structure is the way the Puleh through the female guardian spirits interface with the sexual division of labour in Thai Muslim maritime communities. Hence, the sociological significance of the Puleh on sexual division of labour and production relations is in the centre of analysis.

The Puleh-ceremony coincides with the new fishing season each year and it is apparent that the Puleh is very much a rite of renewal for the maritime communities. The argument that I wish to put forward is that in the Puleh, it is the female guardian spirits - mae yaa nang rya - that play a central role in bringing the sea-based activities of men and the land-based activities of women together in an act of celebration of difference, interdependence and complementarity. In order to understand this it is necessary to explore the concepts of sexual division of labour, kinship and production relations in local maritime communities. Also it is necessary to analyse the meanings bestowed upon the female guardian spirits in local practises.

First the analysis of sexual division of labour, kinship and production relations. The usual pattern of a Thai Muslim household is that of conjugal nuclear family unit where household members are related through kinship and who share common productive 
activities, with specific expectations of labour input, rights of ownership and share of products. However, at a closer look, there is a strong tendency for matrilocal residence in maritime communities, resulting in a pattern in which married daughters form their own households near the daughters' parents' household, forming a family compound in which members trace kinship through the wife. These family compounds are sometimes referred to as khrua ryan cha su (literally hearth shelters of elder and younger sisters).

37 This means that such conjugal nuclear families form family compounds where the sisters' households look after the needs of each other and share productive activities. While members of a particular household identify with a particular dwelling when asked for household membership, it is common for individuals to belong to a group of households that share in productive activities. The crew composition of fishing boats is often made up of a man and his sons and/or his sons-in-law who lives in the family compound.

38 In Thai Muslim society exists a very clear division of labour along gender lines. There are many parallels with other Asian maritime communities in this respect (see, for example Fraser 1966; Firth 1943; Firth 1946; Alexander 1982; Carsten 1989; Stirrat 1989 ; Ram 1991). The evidence from the ethnographies point out to the fact that fishing expeditions take the fishermen away from home for long periods of time, and as women have responsibilities in the domestic domain, they cannot participate in fishing activities. However, in most cases women play a central role in distributing the fish. They also tend to have a more intricate understanding of the market and fluctutations in values of fish.

39 I propose the following simple classification to summarise the sexual division of labour in Thai Muslim maritime society : Men : Politics, religion, education, fishing; Women : Commerce, kinship, community, land.

40 Men are associated with moral/religious power. They are also responsible for the actual catching of fish. Women are associated with commerce as they are responsible for distribution of the fish and are financial managers of the households. They are also associated with kinship and community because of the strong tendency for matrilocal residence, whereas men are more like " affinal visitors".

41 In Phangnga Bay communities, as in many other Asian maritime communities, men go fishing, while women dominate the domestic domain and distribution of products. Due to this arrangement there is an economic interdependence between men and women. Although men produce cash through fishing, women as traders control its use and exercise power within the household. As traders, women act like a channel through which the ideology of the market place enters the village ; controlling the cash, women gain power.

While men do most of the fishing, women do all the household chores and participate in agricultural production, mainly for subsistence. Because they are often away from the community and because of the stress on village exogamy, men move into the village of their wife from outside while women almost always stay in the vicinity of their parent's household.

Women associate with others of the same household, kin and neigh bours. At the core of the house is the khrua (the hearth), where meals are cooked by women and are eaten by co-resident household members. The hearth is a symbol of the provision of 
sustenance and security. The model of community is a collection of similar households, dominated by women, united by close consanguineal ties. Women are therefore endowed with the qualities of kinship and community. Women also have a close connection with land. There is a strong matrilocal tendency in the communities, which favours the acquisition of property through the female line. Females stay in their natal village, and they take the important decisions about investments ${ }^{11}$.

Men are in possession of intricate local knowledge of the marine environment, that they rely on for livelihood. It is important to note that men's and women's worlds are interdependent from each other and that both sexes contribute to the productive activities of the community.

With the concepts of sexual division of labour, kinship and production relations, it is necessary to connect the female guardian spirits into the discussion.

The mae yaa nang rya is considered to be a deceased female relative of the wife of the fishing boat's owner. As we have already seen females in Thai Muslim maritime communities represent the continuity of the community of living and in the case of the mae yaa nang rya, the guardian spirit represents an extension of the community of the living through the female line. The female guardian spirit is also a representation of the hearth shelter of the family compound and the domestic domain in which women play such an important role in providing sustenance and hence enabling continuity of productive activities. At the same time the female guardian spirit of the boat is an embodiment of local knowledge surrounding fishing operations, the realm of male activities. She foretells whether the fishing expedition will be good, which disasters await and intermediates on behalf of the boat crew with other spirits that may impinge on fishing operations. In short the mae yaa nang rya represents both female and male qualities at the same time and hence serves as the connecting point for them.

47 Consequently, the Puleh through its focus on seeking blessings from the female guardian spirit of the boat provides an interface between the world of men and the world of women to come together in a celebration of difference, complementarity and interdependence that is characteristic of Thai Muslim maritime communities social worlds.

\section{Transformation and Continuity}

48 Although the local marine environment continues to be a source of a relatively traditional livelihood for villagers, many villagers also want to take advantage of the opportunities brought by the new ways of using natural resources. One of these new ways is brought about by the emerging tourism industry in the region. A number of younger fishermen have turned their fishing boats into sightseeing boats in order to take tourists to nearby islands that dot Phangnga Bay. This, like tourism in general, is a seasonal phenomenon concentrating on the winter months of November-February, which coincides with the best fishing season. Taking tourists on day trips is considered as « easy money » compared to fishing. Many of the older fishermen complain that the younger men are becoming lazy as they get accustomed to « easy money " they gain with the tourists. It should be stressed that the tourism industry is not only affecting younger men, it is also providing opportunities for women to diversify their productive activities. 

fishing season for fishing boats as well as for the sightseeing boats at the beginning of the new tourist season, attests to the power of continuity of tradition, albeit in a lightly modified form, and the central role the mae yaa nang rya continues to play in bringing the Thai Muslim maritime communities together.

\section{BIBLIOGRAPHY}

Alexander, Paul, 1982, Sri Lankan Fishermen : Rural Capitalism and Peasant Society. Canberra : The Australian National University (ANU Monographs on South Asia ${ }^{\circ} 7$ ).

Anderson, Wanni Wibulswasdi, 1988, « Thai Muslim Children's Play Culture », in A.D. W. Forbes (ed.), The Muslims of Thailand. Vol I : Historical and Cultural Studies. Ranchi : The Catholic Press.

Carsten, Janet, 1989, « Cooking Money: Gender and the Symbolic Transformation of Means of Exchange ", in J. Parry and M. Bloch (eds), Money and the Morality Exchange. Cambridge : Cambridge University Press.

Firth, Raymond, 1943, Malay Fishermen : Their Peasant Economy. London ; Routledge and Kegan Paul. 
Firth, Rosemary, 1946, Housekeeping among Malay Peasants. London : London School of Economics (Monographs on Social Anthropology n7, 2nd ed).

Fraser, Thomas, 1966, Rusembilan : A Malay Fishing Village in Southern Thailand. Ithaca : Cornell University Press.

Klin, Khongmuangphet, 1993, Wattanatham lum nam krabi yai (Culture around the Krabi River). Withalayaipholsyksaa changwat : Suunwattanatham changwat krabi.

Ram, Kalpana, 1991, Mukkuvar Women : Gender, Hegemony and Capitalist Transformation in a South Indian Fishing Community. London : Zed Press.

Ruohomäki, Olli, 1999, Fishermen No More? Livelihood and Environment in Southern Thai Maritime Villages. Bangkok : White Lotus.

Stirrat, R L., 1989, « Money, Men and Women », in J. Parry and M. Bloch (eds), Money and the Morality Exchange. Cambridge : Cambridge University Press.

Tambiah, Stanley J., 1970, Buddhism and Spirit Cults in North-East Thailand. Cambridge : Cambridge University Press.

\section{APPENDIXES}

\section{GLOSSARY}

Unless otherwise specified the glossary includes words in local Thai.

ao bay

bet line and hook

chao thi guardian spirit

hin tai nam underwater rock

huay channel

katha spell

khamin turmeric

khrua hearth

kongkang bailek a mangrove species, Rhizophora apiculata

laem cape

loom portable fish trap

lok winyaan the world of spirits

mae yaa nang rya the female guardian spirit of the boat

ma'r bride wealth nam mon lustral water

phi jin sea spirit, the word jin has arabic roots

phong ba mangrove bark

po a large sedentary weir

sai myk squid trap 
samae khao a mangrove species, Avicennia alba

taboon a mangrove species, Xylocarpus

to mo ritual specialist

uan loi drift gill-net

uan run push-net

\section{NOTES}

2. This article is a contribution to the knowledge on maritime societies and the relationship between ritual and gender. The information presented here is based on my field research in Phangnga Bay, Krabi province, Southern Thailand in 1993-94. A full ethnographic account of the maritime villages in Phangnga Bay is presented in my 1999 book.

3. The mangrove plant has medicinal uses. The powder from the Rhizophora bark can be used to cure diarrhoea by being boiled for its juice and to stop bleeding by being crushed and placed on the wound. The stem of the Avicennia alba and Avicennia officialis (samae dum) is boiled and the extract is used as a cure for general debility. Xylocarpus (laboon) seeds are also used to treat diarrhoea and the Acanthus species can cure skin rash. In addition, village curers use mangrove bark powder (phong ba) in the annual boat-blessing ceremony.

4. The boat-blessing ceremony is by far the most important ritual performed by the fishermen during the year. There are other rituals related to the life cycle of the villagers and social life of the village during the year, but in terms of local livelihood structure, the Puleh is the most important ceremonial occasion.

5. Belief in the spirit world and spirit cults is a very wide spread trait of religion in Thailand. Both Islam and Buddhism is very much intertwined with animism (Tambiah 1970).

6. Among the Malay-speaking Muslims in Pattani, the to mo is called bomo (Fraser 1966 : 58).

7. It is worth noting that sticky rice is not a staple food in contemporary Southern Thailand as is the case in North-eastern Thailand. Rather it is eaten as a dessert. However, a number of to mo told me that the guardian spirits like sticky rice as it was the staple food of the people in Southern Thailand in historical times (cf. Klin 1993).

8. Phangnga Bay is located in the transition zone between the southern Islamic Malayan world and the central and northem regions of Buddhist Thailand. Both Muslims and Buddhists are found in the region. The great majority of the Muslims, who adhere to the Shafi'i school of Islam, which is the predominant form of Islam in Southeast Asia, are found in coastal fishing villages whereas the Buddhists are found in inland agricultural villages and towns. Precisely when Islam arrived in the area is not known. It is probable that Islam spread from the south along with fishermen who settled along the coast in the last century. Most of these people came from as far away as Satun, which was once part of the Pattani principality.

9. Unfortunately I do not have any information on the kinds of rituals associated with the female guardian spirits among the Thai Buddhist fishermen.

10. Khamin is frequently used in different kinds of offerings made to the spirits.

11. Women usually decide to invest in land. For example, among wealthier households a large portion of the ma'r (bridewealth) is increasingly often invested in land. In other words, land is becoming " gendered» in many communities along the coast of Phangnga Bay.

12. While the presence of popcorn remains a mystery to me - perhaps a representation of modernity? - the cash denotes to the currency obtained from tourists. 


\section{ABSTRACTS}

Each year at the end of the monsoon season and the beginning of the new fishing season, Thai Muslims in Phangnga Bay, Southern Thailand, perform a boat blessing ceremony known as Puleh in the local dialect. The purpose of this ceremony is to ask for guidance and success for the coming fishing season from the female guardian spirits (mae yaa nang rya) believed to be residing in the fishing boats. The fishermen earn their livelihood by exploiting marine resources in a relatively uncertain environment and although they possess an intricate understanding of their local marine environment, no fisherman would think of solely relying on himself. The Puleh ceremony combines pre-Islamic beliefs and marine lore into a rite of passage for the entire community. The Puleh provides an interface for the worlds of men and worlds of women to come together in a celebration of difference, complementarity and interdependence, that is characteristic these communities. Despite social and economic transformations, the Puleh retains its significance in social practises as attested by the fact that it is also performed on fishing boats that have been turned into tourist boats.

Chaque année, à la fin de la mousson et au début de la nouvelle saison de pêche, les Thaï musulmans de Phangnga (sud de la Thaillande) accomplissent une cérémonie nommée Puleh dans le dialecte local. Par ce rituel, on demande protection et assistance aux esprits gardiens féminins (mae yaa nang rya), qui selon la croyance, résident dans les bateaux de pêche. Les pêcheurs évoluent dans un environnement marin incertain, et malgré leur fine connaissance du milieu, aucun d'entre eux n'envisagerait de se passer de cette assistance. La cérémonie du Puleh combine des croyances pré-islamiques et la tradition marine en un rite de passage concernant la communauté entière. Le Puleh assure l'interface entre le monde des hommes et celui des femmes dans une célébration de la différence, de la complémentarité et de l'interdépendance, une spécificité sociale de ces communautés. En dépit des changements, ce rituel garde une signification dans les pratiques sociales. En atteste le fait qu'on l'accomplit encore sur des bateaux destinés au tourisme.

Cada año, al terminarse el monzón y cuando empieza la nueva temporada de pesca, los Tai musulmanes de Phangnga realizan una ceremonia nombrada Puleh en el dialecto local. Con este ritual, se pide la protección y el socorro de los espíritus femeninos (mae yaa nang ry), que residen -según las creencias - en los barcos de pesca. Los pescadores se desplazan en un medio maritimo imprevisible, y aunque lo conocen profundamente, ninguno de ellos pensaría pasarse sin la asistencia de dichos espíritus. En la ceremonia del Puleh se combinan creencias preislámicas y la tradición de los marinos, en el cuadro de un rito de pasaje que concierne al conjunto de la comunidad. El Puleh proporciona el interfaz entre los respectivos mundos de los hombres y de las mujeres, en una celebración de la diferencia, de la complementaridad y de la interdependencia, lo que constituye una especificidad social de estas comunidades. Pese a los cambios, este ritual conserva una significación en las prácticas sociales. El hecho de que se sigue realizando en los barcos de turismo lo averigua.

\section{INDEX}

Mots-clés: Thaï musulman, Thaïlande, rituel, genre, tradition marine 


\section{AUTHOR}

OLLI RUOHOMÄKI

Adviser with the Department for International Development Cooperation, Ministry for Foreign Affairs, Finland 